\title{
Cultural Tourism Policy in Manado
}

\author{
$1^{\text {st }}$ Ferdinand Kerebungu \\ Sosiology Education Department \\ Fakulty of Social Science, Universitas \\ Negeri Manado \\ Manado, North Sulawesi \\ ferdinankerebungu@unima.ac.id \\ $4^{\text {th }}$ Apeles Lexi Lonto \\ Pancasila and Civic Education \\ Department \\ Faculty of Social Science, Universitas \\ Negeri Manado. \\ North Sulawesi \\ lexi.lonto@unima.ac.id@unima.ac.id
}

\author{
$2^{\text {nd }}$ Theodorus Pangalila \\ Pancasila and Civic Education \\ Department \\ Faculty of Social Science, Universitas \\ Negeri Manado, \\ North Sulawesi \\ theopangalila@unima.ac.id \\ $5^{\text {th }}$ Julien Biringan \\ Departement of Pancasila dan Civics \\ Education \\ Faculty of Social Manado State \\ University \\ Manado, Sulawesi Utara \\ julienbiringan@unima.ac.id
}

\author{
$3^{\text {rd }}$ Recky Sendouw \\ State Administartion Department, \\ Faculty of Social Science, Universitas \\ Negeri Manado, \\ North Sulawesi \\ Manado, Indonesia \\ reckysendouw@unima.ac.id
}

\begin{abstract}
This research aims to see how far the effect of tourism towards cultural tourism's development in Manado. The object of this research is the elements of culture that possessed by citizen in Manado that can become asset of tourism in Manado. This study is survey research type. In collecting the data, technique of interview, observation and literature study were used. The data that had been collected qualitatively altogether with secondary data were analyzed ethnographically simple. This research concludes that the diversity of ethnics concealing potencies which can be developed becoming tourism asset. The potency that possessed by Manado is in the form of diverse traditional cultural arts that can be developed into tourism asset.
\end{abstract}

Keywords-Policy, Tourism, Culture

\section{INTRODUCTION}

Tourism is one of the assets that can be developed by an area / region in order to increase tourist visits both domestically and internationally. With the increase in tourist visits will have a rapid impact on economic growth both the community around the location of tourism objects and the area as a whole. The increasing economic growth of the community and the region will also have a positive impact to increase local revenue (PAD), an increase in PAD as a whole will be able to support development in various sectors and improve the welfare of the community.

One of tourism asset which can be developed is cultural tourism, whereas this culture possesses its own uniqueness that attracted domestic even foreigners tourists. This can be seen of how cultural tourism object effloresced well in Javaness island and Baliness island, whereas that had been attracted international adn domestic tourists in the adequately significant amount, so that this sector turn into a pivot mainstay in Locally-generated revenue (PAD) especially in Baliness island and significantly have impact in increasing national revenue.

Cultural tourism, for North Sulawesi especially Manado until now has neither get serious atention from the government nor any private that running tourism sector. If this asset being observed well it will eventually give a significant impact in increasing society's welfare in Manado.
Therefore, this cultural tourism needs to be investigated and developed priory in order to concreting Manado become Eco-Tourism model city which now is being promoted to be the icon of Manado. The investigation is needed a thoughtful study in relation to the cultural potential that possesed by Manado, and also an investigation concerning cultural dynamics that is developed in Manado that possesed by the multidimentional and multicultural society. To the multidimentional and multicultural society it has been a very potential asset to develop cultural tourism. Therefore, a thoughtful investigation and further reseach to be able to know the potential and the types of culture that can be developed to be tourism asset that can be promoted by the Government of Manado, as the means to develop regional potency.

The attempt to comprehend social cultural dynamics and any society's community that in a particular tourism destination region requires a thoughtful comprehension so that can be found whether by the increasing of current tourism visitation in the tourism destination area can give a significant contribution towards the society around the tourism object. The area of National Marrine Park of Bunaken is one of tourism destinations asset that possessed by Manado, whereas an island that populated by the inhabitant from Sangihe ethnic and Talaud, so that from this island, cultural tourism can be developed beside maritime tourism as well. Bunaken island is tourists' transit island before having maritime tourism to enjoy the beauty of the nature in Bunaken National Marine Park. Hence, the investigation towards social cultural dynamics of the society around toursim object is really needed, in order to attain accurate information about the development of society's life at the tourism object.

Had contemplated economically, tourism sector apperently have bright prospect to increase foreign exchange of the nation, which is by the visitation of the international tourists that come at the tourism destination region. Besides, tourism can also increase Locally-generated revenue (PAD) and can accomodate manpower/ labor force even opening bussines opportunity for the society around it. However, behind them, tourism in assence is the encouter among foreign culture that brought by international tourists 
and modern culture that whether it is brought by domestic and urbane with local culture and society surround the tourism object area. Hence, even though tourism can increase foreign exchange but tourism can become one of the causal factors from the social cultural effect as well priory society's life style surround it, so that every development of the tourism asset needs to consider the following effect of it.

The establishment of tourism sector that expected to be national foreign exchange income. Tourism sector basically can give significant contribution onto national or regional income, national income contribution from the tourism sector can be concrete if synergy among government, private and society, in which together giving the best service towards the tourists. The best service can be in the form of the availability of the adequate infrastructure, maintenance policy, whether it is from the government or private sector. In order to establish it, it is really requires a serious attempt from the government in preparing for various policies that encourage the established competitive and conducive circumstance through market mechanism which involved private sector nor society labor institution (LSM) so that national foreign exchange through tourism sector able to be increased without puting any burden to the government.

On the other hand, in enhancing service at the tourism sector, the executor party whether it is government or private are unable to ignore society that is around the tourism object location. The role of the society in sustaining tourism conduction is really needed (e.g Bali), since by involving society, the executor party get a cheap labor but harmless that labor in other words occured a mutual symbiosis proces. Had this proces happened indirectly executor party had increased society's welfare.

Society involevement here can be in the form of tour guide, providing food material, cheap cottage, and providing souvenir. However in reality nowadays, society that is in Bunaken and Siladen Islands had not fully involved yet, or even not being involeved at all, and even though it had it is not as significant as the populate inhabitant. Consequently society's behaviour at the tourism object area at Bunaken Marine Park are less responsive. This is because they were less likely to be involved in tourism activity. Currently in general tourism activity in Bunaken marine park directly handled privately by tourism explorere party or diving manager that notably populated in Manado with the labor force from Manado or out of the inhabitan from Bunaken district especilly people that is in Bunaken island itself.

Therefore, in developing tourism asset, it requires a well planned planning through a thoughtful research, so that a kind of tourism instrumental planning development able to be resulted from the the study. That instrument can become a guideline in composing policy, pattern and types of culture that are able to be developed as tourism cultural mainstay. From that instrument can also be seen the effect that needs attention so that the negative effects able to be minimized.

Based on the background of the study above, that this research attempted to see how far the impact of tourism towards cultural tourism development in Manado.

\section{RESEARCH METHODS}

The object of this research is cultural elements that possessed by the people/society of Manado that can be turn into tourism assets in order to determine the policy in developing tourism in Manado. This study is a type of survey research. In collecting the data, interview, observation and literature study techniques were used. The data that had been collected qualitatively altogether with the secondary data will be analyzed etnographically simple.

\section{RESULTS AND DISCUSSION}

The term tourism is closely related to the notion of tourism recognition, namely as a change in the temporary place of residence of someone outside his residence for a reason and not to carry out activities that generate wages. Tourism is a journey from one place to another, is temporary, carried out by individuals or groups, as an effort to find balance or harmony and happiness with the environment in social, cultural, natural and scientific dimensions. Tourism is a journey that is carried out temporarily, held in a place to another place with the intention of not trying or making a living in the place visited but solely to fulfill various desires [1]

According to Sadhana in Public Policy Reality there are four (4) factors that interact with each other in policy implementation, namely communication factors, resource factors, disposition factors or attitudes, and organizational structure factors [2]. According to references [3] and [2], "Public policy is whatever governments choose to do or not to do." Dye argued merely that public policy is whatever the government chooses to do or not do.

The aim of the Tourism development program is to develop and expand product diversification and the quality of national tourism in general and the region in particular based on community empowerment, arts and culture as well as resources (charm) of local nature while maintaining the preservation of traditional arts and culture as well as local environmental sustainability and develop and expand the tourism market, especially foreign markets [4]

According reference [5] culture is: "an historically transmitted pattern of meanings embodied in symbols, a system of inherited concepts expressed in symbolic forms by means of which to communicate, perpetuate, and develop their knowledge about and their attitudes toward life." From this definition Geertz explains that culture is "the historical transmission pattern of meanings included in symbols, or a system of conception that is presented and inherited in the way humans communicate, namely in the form of symbols, develop and preserve the knowledge they have and how they respond to their lives. "Based on its definition of culture, Geertz wants to emphasize that culture is an active and constitutive dimension of social life rather than just a mechanism to guarantee social integration. Geertz sees culture as a "symbolic curve" or "blueprint" by which one can create their meaningful world at two levels at once: emotional and cognitive [6]. Cultural art potency that possessed by the people in Manado that are cultural assets to sustain tourism program of Manado needs to be designed in such way so that able to to be tourism object in Manado. Culture potential that possessed by them such as Maengket and Hasa Dance, had those being managed well it could inevitably become assests of tourism that is very potential that have crucial values for the the tourism development. Hence, it is a must that all kinds of arts that they had to be developed and preserved so that it would not being scraped 
of the negative effects that probably emerge as the causal of the rapid building.

According to Kluckhohn in [5], culture can be interpreted as follows: (1) "the total way of life of people of a people"; (2) "the social legacy of the individual acquires from his group"; (3) "a way of thinking, feeling, and believing"; (4) "an abstraction from behavior"; (5) a theory on the part of the anthropologist about the way in which a group of people in fact behaves; (6) a "store-house of pooleed learning"; (7) "a set of standardized orientations to recurrent problems"; (8) "learned behavior"; (9) a mechanism for the normative regulation of behavior; (10) "a set of techniques for adjusting both the external environment and to other men": (11) "a precipate of history" ... From the above definition, according to Kluckhohn the culture includes: (a). Total human way of life, (b). Social inheritance of individuals obtained from the group, (c). A way of thinking, feeling, and trusting, (d). An abstraction from behavior, (e). A theory in anthropology about how a group of people in a group behaves a combination of what is learned, (f). All basic guidelines for solving problems, (g). Learning behavior, (h). A standard regulatory mechanism for behavior, (i). All techniques for adjusting to the environment outside and to others, (j). An application of history and turning, perhaps in despair, as a figure of speech, like a map, like a filter, and like the arrangement of numbers [7].

Based on the asumption, the cultural potencies need: (1) giving a comprehension about the meaning of the traditional art as elaborated above as the cultural wealth which have high values, (2) giving a particular information towards society about the appropriate preservation mechanism, (3) giving infromation and training about managing and developing traditional cultural art to share society's various importance generally, and (4) giving information and comprehension concept towards society that by preserving traditional cultural art can contribute to foreign exchange for the government and wide society.

Thus, to be able to implement cultural art as an asset of tourism in Manado, that a set of instruments required to be managed as the guideline/reference of the execution. That instrument was a reference for the government of Manado in order to prepare and stabilize the planning program of becoming eco-tourism city. By developing cultural potency that is in Manado means Eco-Torism can be established in the social and culture of the society. The problem now is the young generation that does not know and feel inconvenient to demonstarte the traditional cultural art, since it is seemed old or ancient for them.

Cultural art potency that possessed by society in Manado will not be able to develop more and cannot being materialized as tourism asset without doing any further process or action. The proces can be ran well and succesfully if it will be planned well and organized, so that the proces able to be impemented as expected. Thus, in increasing such cultural tourism asset, the policy and regulation are required to be setled by the government so that the development could be clear. Some instrments that can become a reference in implementing cultural art development program as tourism asset.

\section{A. Establishing Art Gallery}

It is considerably potential for the majority of any particular ethnic in each district to gain advantages by establishing art gallery. The aims to establish it is to create regeneration towards the development of cultural art which is potential in that district. Besides, the objective of establishing art gallery is to facilitate coordination and the management of fund distribution. The convenience of coordination were meant for if there is any request of tourists in particular specific place in Manado or any show activity towards governmental guests or private, that when the members were needed to assamble the members of a particular art gallery would have less difficulty. Meanwhile the convenience in distributing the fund, was meant to manage each fund sharing easily and the leader of art gallery will be in charge of it.

\section{B. Inter-schools Competition}

School is the best place to do art development guidence, since students still bounded in the school whether it is at the level of elementary, junior and even high school. The most ideal level in developing art are at the level of elementary and junior high school. Inter-schools competition is one of the means of competition inter-school towards traditional art which being learned by them so that through it, each school will be competing to promote or train their students about some traditional arts. To facilitate the execution, traditional art can be adjusted in the curriculum or local subject that the supervising of it could be under Department of Urban Education and concerning the technical of conduction can be done every national education day, or celebrating Manado's Birthday and independence day of the Repblic of Indonesia.

\section{Art Fest (Art Festival)}

Art festival is a pageant of competition of every sanggar seni (art gallery) or art competition that is in every particular districts. Art festival aims to encourage each sanggar seni to tydi up and increasing its sanggar skills in the process of guidance the development of traditional cultural art. It can become agenda of the tourism year from the government of Manado, so that government were able to determine the schedule of that festival and being adjusted with government calendar of activity, such as Pigura festival, Tulude and etc.

\section{Mapping of Potential Region of the Tourism Asset Development}

Then Edward B. Tylor (1871) as quoted by [8] that culture is: "that complex whole which includes knowledge, belief, art, morals, law, custom, and any other capabilities and habits aquired by man as a member of society ". Culture or civilization is a complex totality of belief, art, knowledge, law, law, customs, and other habits and abilities acquired by humans in essence as part of a society. There are some districs that populated by a particular ethnic and has cultural art which can become developing asset of tourism in Manado. The ethnics who are potential to be developed is Manahasa ethnic, Sangihe-Talaud, Bantik and Borgo. Therefore, mapping of regional potency needed to be conducted to facilitate the party from the government and private to preserve the development of cultural art community of each ethnic. 


\section{E. The Engagement of Private Party}

In the process of developing cultural art in Manado would still be inadequate if only engaging government, since government itself had a limitation whether it is energy or fund. Thus, government considerably would be better to encourage any private party for actively involving for the role of tourism asset development that existed. The involvement of this private party was not merely towards the development and preservation, but promoting tourism potency in Manado as well. This promotion will absorb great power/energy and fund. Since promotion was not merely conducted inside the nation itself but also international.

\section{F. Mass Society Engagement}

The involvement of the government and any private sector would not be succesfully attained if not being sustain by mass society generally. Society's engagement that is meant in here is in order to preserve and maintain the cultural tourism assests, and direct engagement of the society elements in every activity of developing cultural art that existed in Manado. Had so, that what had been programmed and planned by government to make Manado as city of Eco-tourism model can be realized well.

\section{G. The Determination of Cultural Performance and Festival Calendar}

Making clear the time of cultural performance and festival by government of Manado, so then time setlement, which is date and month of conduction at the year that is running. This determination of time will facilitate the process of promoting the tourism potency that existed in Manado. Besides, time that had been determined clearly facilitate all tourists in scheduling their tourism exploration to Manado.

\section{CONCLUSION}

Based on the result of the discussion in this research that being conducted, thus it is deduced that the diversity of ethnics become a very beneficial advantage for the development of cultural tourism in Manado. In the attempt of developing Manado becoming city of the Eco-Tourism Model the engagement of the government and private sector even whole elements of the society were needed as well. Furthermore, this research recomends the government of Manado to keep develop and preserve traditional cultural art which became tourism assets.

\section{ACKNOWLEDGMENT}

We would like to say thanks to the Rector of Manado State University who has facilitated the research and writing of this article, also to our fellow research team and writers. Thanks also to the Committee of International Conference on Social Science (ICSS) and the Atlantis Press Publisher which has facilitated the publication of this article.

\section{REFERENCES}

[1] S. B. Kairupan, "Privatisasi Sektor Pariwisataa, (Studi Kasus implementasi Kebijakan Privatisasi pada Obyek Wisata Bahari Taman Laut Bunaken, di Kota Manado Provinsi Sulawesi Utara," Universitas Brawijaya Malang, 2001.

[2] K. Sadhana, Reality kebijakan public. Malang: UM Press, 2012.

[3] T. R. Dye, Understanding of Public Policy. New Jersey: Prentice Hall, 1996.

[4] Sedarmayanti, Mengembangkan Kebudayaan dan Pariwisata (Bunga Rampai Tulisan Pariwisata), Mandar Maju. Bandung: Mandar Maju, 2005.

[5] C. Geertz, "Common sense as a cultural system," Antioch Rev. vol. 33, no. 1, pp. 5-26, 1975.

[6] M. Sutrisno and H. Putranto, Teori-Teori Kebudayaan. Jakarta: Kanisius, 2005.

[7] C. Geertz, The Interpretation of Cultures: Selected Essays. New York: BASIC Books (NY), 1977.

[8] R. Munch and N. J. Smelser, Theory of Culture. California: University of California Press, 1992. 